\title{
Erratum
}

\section{Erratum to "Readiness of Sub-Saharan Africa Healthcare Systems for the New Pandemic, Diabetes: A Systematic Review"}

\author{
Bernardo Nuche-Berenguer $\mathbb{D}^{1}$ and Linda E. Kupfer $\mathbb{D}^{2}$ \\ ${ }^{1}$ National Institute of Diabetes and Digestive and Kidney Diseases, National Institutes of Health, Bethesda, MD 20892-1804, USA \\ ${ }^{2}$ Fogarty International Center, National Institutes of Health, Bethesda, MD 20814, USA \\ Correspondence should be addressed to Linda E. Kupfer; kupferl@mail.nih.gov \\ Received 8 May 2018; Accepted 10 June 2018; Published 8 July 2018 \\ Copyright (c) 2018 Bernardo Nuche-Berenguer and Linda E. Kupfer. This is an open access article distributed under the Creative \\ Commons Attribution License, which permits unrestricted use, distribution, and reproduction in any medium, provided the \\ original work is properly cited.
}

In the article titled "Readiness of Sub-Saharan Africa Healthcare Systems for the New Pandemic, Diabetes: A Systematic Review" [1], the format of Table 1 was unclear. The updated table is shown below.

TABLE 1: Examples of interventions to improve patient adherence to diabetes treatment in SSA.

\begin{tabular}{|c|c|c|}
\hline Country & Summary of intervention & Outcomes \\
\hline $\begin{array}{l}\text { Mozambique [42] } \\
\text { Rwanda [50] }\end{array}$ & $\begin{array}{l}\text { Improvement of care through establishment of } \\
\text { partnerships and systematic care }\end{array}$ & $\begin{array}{l}\text { Increased information about diabetes and access to care } \\
\text { for patients }\end{array}$ \\
\hline $\begin{array}{l}\text { Cameroon }[27,66] \\
\text { Kenya [33] }\end{array}$ & Integration of diabetes care into primary care facilities & $\begin{array}{l}\text { Reduced transportation barriers and improved patient } \\
\text { retention rates }\end{array}$ \\
\hline $\begin{array}{l}\text { Kenya [52] } \\
\text { DRC [68] }\end{array}$ & Cell phone-based home glucose monitoring programs & The clinical outcomes have not been evaluated yet \\
\hline Kenya [34] & Establishment of home-based screening for diabetes & No improvement in clinical outcomes \\
\hline $\begin{array}{l}\text { Nigeria [69] } \\
\text { Kenya [35] } \\
\text { Cameroon [70] }\end{array}$ & Introduction of self-monitoring blood glucose programs & No improvement in clinical outcomes \\
\hline South Africa [67] & Establishing of mobile testing units & Improvement in linkage to care \\
\hline Ghana [71] & $\begin{array}{l}\text { Setting off electronic reminders on risk management for } \\
\text { diabetic patients }\end{array}$ & Increased adherence to treatment and reducing of FBG \\
\hline $\begin{array}{l}\text { Cameroon }[72,73] \\
\text { Kenya }[36,44]\end{array}$ & $\begin{array}{l}\text { Different approaches to establish peer support for } \\
\text { diabetes patients }\end{array}$ & $\begin{array}{l}\text { Increased adherence to treatment and improvement in } \\
\text { clinical outcomes }\end{array}$ \\
\hline
\end{tabular}




\section{References}

[1] B. Nuche-Berenguer and L. E. Kupfer, "Readiness of subSaharan Africa healthcare systems for the new pandemic, diabetes: a systematic review," Journal of Diabetes Research, vol. 2018, Article ID 9262395, 12 pages, 2018. 


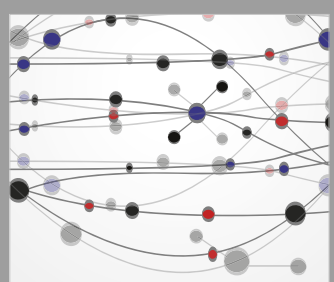

The Scientific World Journal
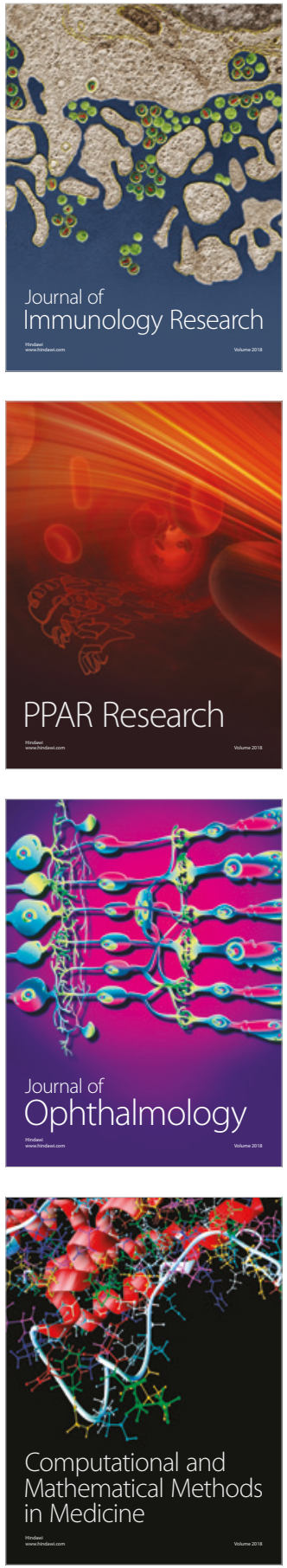

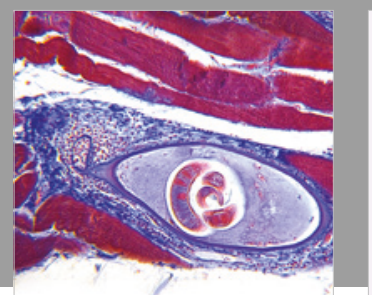

Gastroenterology Research and Practice

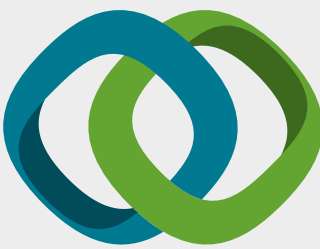

\section{Hindawi}

Submit your manuscripts at

www.hindawi.com
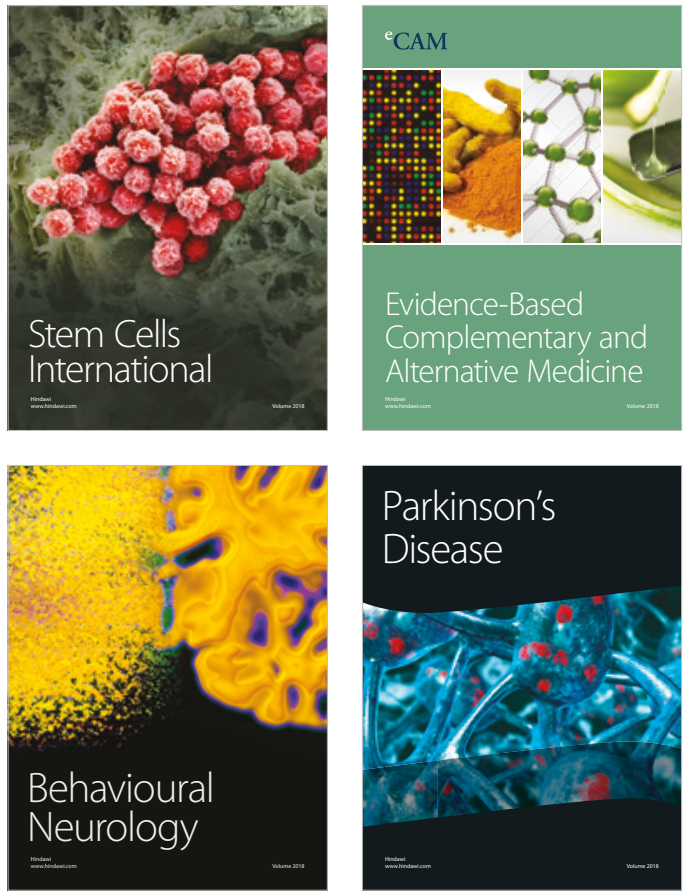

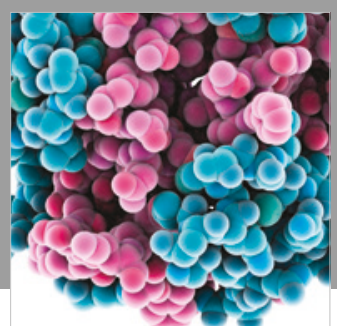

ournal of

Diabetes Research

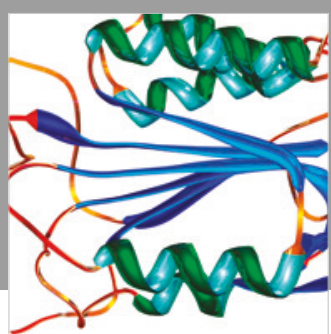

Disease Markers
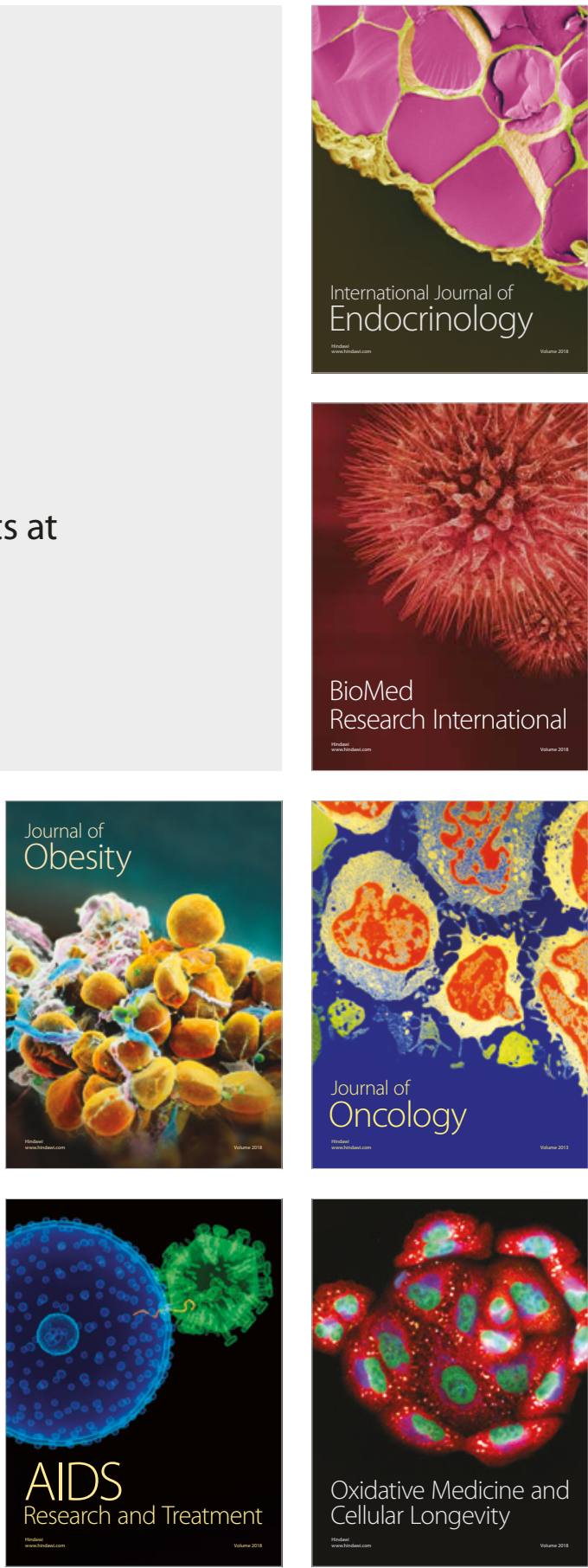